\title{
Algebraic Reasoning in Early Grade: Promoting through Lesson Study and Open Approach
}

\author{
Pimlak Moonpo $^{1}$, Maitree Inprasitha ${ }^{2}$, Narumon Changsri ${ }^{2}$ \\ ${ }^{1}$ Doctoral Program in Mathematics Education, Khon Kaen University, Khon Kaen, Thailand \\ ${ }^{2}$ Mathematics Education Program, Faculty of Education, Khon Kaen University, Khon Kaen, Thailand \\ Email: Pimlak_m@hotmail.com
}

How to cite this paper: Moonpo, P., Inprasitha, M., \& Changsri, N. (2018). Algebraic Reasoning in Early Grade: Promoting through Lesson Study and Open Approach. Psychology, 9, 1558-1569.

https://doi.org/10.4236/psych.2018.96094

Received: May 8, 2018

Accepted: June 26, 2018

Published: June 29, 2018

Copyright $\odot 2018$ by authors and Scientific Research Publishing Inc. This work is licensed under the Creative Commons Attribution International License (CC BY 4.0).

http://creativecommons.org/licenses/by/4.0/

\begin{abstract}
The objective of this study is to analyze what characteristics are of early grade students' algebraic reasoning in context of open approach and lesson study. Ethnographic study was employed to conduct in this qualitative study. The study was carried out in one mathematics classroom which is a case study of this study and it is the case of classroom which has been using open approach and lesson study since 2006. The 3 teachers are as a member of school lesson study team participated the study as informant and so were 10 students from the class. The data were collected through 9 consecutive lessons by observation with audio-video tape recording, interview, students' written works and daily field notes. The lessons were designed by carrying into 4 steps of open approach: posing problem, students' self-learning, whole class discussion and comparison, and summing-up by connecting students' emergent mathematical ideas. All activities were guided by Thai version of $1^{\text {st }}$ grade Japan mathematics textbook. The results showed that characteristics of first grade students' algebraic reasoning are as follows: 1) using algebraic expressions to represent addition situation and posing situation to represent given expressions, 2) constructing and using a tool to find problem results more easily, 3) extending solutions to another domain of number, 4) using various representations to justify their ways of thinking, and 5) reasoning about relations among numbers. The algebraic reasoning occurred under the condition that teachers and students had connected among 3 worlds oriented to Inprasitha's approach: real world, semi-concrete world, and mathematics world.
\end{abstract}

\section{Keywords}

Algebraic Reasoning, Early Algebra, Lesson Study, Open Approach

\section{Introduction}

Teaching and learning algebra has been transformed about 20 years, the idea 
"algebra for all" is accepted by many educators (Howden, 1990; Lodholz, 1990; NCTM, 2000; Jacobs et al., 2007) and "Algebra for Everyone" was published to gather ideas for teaching and learning algebra for everyone (NCTM, 1990). Traditionally, algebra has been started at secondary level because of at least three reasons: algebra emerged after arithmetic historically, psychological readiness on learning abstract like algebra, and difficulties that students have with algebra (Carraher, Schliemann, Brizuela, \& Earnest, 2006). According to these reasons, students have been considered to learn algebra after they had acquired adequate essential arithmetic (Lins \& Kaput, 2004; Radford, 2012). The acceptance of "algebra for all” takes different views from traditional teaching and learning algebra which is taking Piagetian view of learning (cognitive precedes learning). Nowadays, this tradition is still taken in many countries (Lins \& Kaput, 2004). Since 1990 many educators have accepted the idea that does not conform to cognitive development, they take the idea of Vygotsky which learning precedes development. Increasing the number of educators, researchers, and policy makers who believe that students at elementary grades should have experience in algebra so that they will be able to access formal algebra better at later grades (Carraher, Schliemann, Brizuela, \& Earnest, 2006; NCTM, 2000; Lins \& Kaput, 2004; Blanton \& Kaput, 2005; Smith \& Thompson, 2007; Cai et al., 2005). Study algebra at very young age helps students to understand mathematical structure and generality (Blanton \& Kaput, 2011). National Council of Teachers of Mathematics (2000) is also consistent on this belief; it sets algebra as a standard that all students at all levels have to learn.

\section{Algebraic Reasoning in Early Grade}

Although many educators accept the notion that all students must learn algebra, there are still some difficulties such as teaching approach, definition of algebra that cannot make the goal succeeded. Definition of algebra (domain for algebra) is one cause of obstacle, we can be noticed this issue by realizing that at first mathematics educators and related organization had put their effort to define what is algebra for young student, which is consistent with "algebra for all" and young student can learn it. (Yackel, 1997; National Council of Teachers of Mathematics, 2000; Stacey \& Chick, 2004; Kieran, 2004; Inprasitha, 2016a) Inprasitha also pointed out that in order to make algebra for all we need to reconsider what is algebra because it affects curriculum and teaching aspect (Inprasitha, 2016b). Therefore, algebra should not mean solving equation system, finding unknown, using quadratic equation or using formula with letter as same as traditional school algebra (NCTM, 1994 cited in Yackel, 1997; Stacey \& Chick, 2004; Kieran, 2004, Cai et al., 2005). Especially in curriculum perspective, it is impossible to locate algebra in early grade if we take algebra as domain regarding variable and finding unknown (Inprasitha, 2016a). Many mathematics educators had tried to define algebra for early grade students and they define that it is not restricted only in algebra domain but students can access algebra through arith- 
metic learning (Lins \& Kaput, 2004; Kieran, 2004; Cai et al., 2005; Blanton \& Kaput, 2005; Carraher, Schliemann, Brizuela, \& Earnest, 2006). Lins \& Kaput (2004) pointed out that any content domain can support algebraic thinking which is claimed as a part of algebra in early grade. Inprasitha (2016a) also proposes that without refraining with algebraic content, we do not need an algebraic curriculum in primary grade but students can learn algebra through reasoning, and it can be stressed at early grade and in any content. Thus, goal of mathematics learning is turn out to be students' reasoning and thinking. Therefore, in this study algebraic reasoning for early grade focused on students' reasoning with some of following aspects:

1) Using algebraic expressions to represent addition situation and posing situation to represent given expressions

2) Constructing and using a tool to find problem results more easily

3) Extending solutions to another domain of number

4) Using various representation to justify their ways of thinking

5) Reasoning about relations among numbers

\section{Context of Study}

Foundation of algebraic reasoning in early grade can be developed by encouraging students to reason about relationship about quantity and how to represent notation and symbol, to reason beyond specific number (Yackel, 1997). Japan Mathematics Curriculum does not determine algebra as a content domain but it is included in number and operation, quantity and measurement, and geometry by learning through mathematical relations (Isoda, 2010). It was interesting that how Japan integrates algebra in very early grade without defining algebra as a domain to study. Stephens \& Armanto (2010) had studied 1 - 6 grade Japan mathematics textbook and found that the textbook series can support students' relational thinking, which is considered as one kind of algebraic reasoning. Consequently, from their study it is said that we can develop students' algebraic reasoning at very early grade like first grade. So, it's no doubt that Japanese mathematics textbook is well designed to support students' algebraic reasoning.

In the case of Thailand, Japanese mathematics textbook series have been used for the Mathematics Teachers Professional Development using Lesson Study and Open Approach which is initiated by Maitree Inprasitha since 2002. The textbook is consistent with the theory for teaching mathematics in Japan, problem-solving approach, which is believed that students will be able to learn through facing with difficulties in problem solving (Stigler \& Hiebert, 1999; Inprasitha, 2014). One feature of problem-solving approach is Open-ended problem is usually used to encourage students to solve problem by their own satisfied way of thinking (Shimada, 1997). Students can express their algebraic reasoning through solving Open-ended problem (Carraher, Brizuela, \& Schliemann, 2000).

Lesson Study and Open Approach are integrated in Thailand, it is the cooperation of 4 phases of Open Approach as a teaching approach and 3 steps of Les- 
son Study Process as a weekly cycle for developing teaching (Inprasitha, 2011). The aim of integration is to create problem-solving classroom in Thailand and it can be shown as Figure 1.

Conducting Lesson Study and Open Approach does not mean follow those steps manually but teachers need to be aware that what their students must learn mainly is not math content but "learning how to learn". There was an evidence that the teacher in this classroom can make her students to learn "how to learn" (Inprasitha, 2011). Inprasitha (2013) proposed the idea which is called Flow of Lesson, he mentioned that in order to make problem-based classroom students should have opportunity to learn through solving problem and making connection between representation of real world, semi-concrete world, and representation of mathematical world. In this research we did not inform anything about algebraic reasoning to the teachers but focus on flow of lesson, encourage them to continue Lesson Study and Open Approach and the teachers had some advices from experts on PCK occasionally. The school has conducted Lesson Study and Open Approach since 2006 and it has lesson study groups divided by grade band. The teachers had been teaching in school, Khoo Kham Pitthayasan, it is in Khon Kaen province, the Project School of Mathematics Teachers Professional Development using Lesson Study and Open Approach which is conducted by Center for Research in Mathematics Education. As we mentioned above the teacher has used Japanese mathematics textbook to plan all the lessons for more than 10 years so she quite well understand the objective of each lesson. Normally in this classroom, while 1 of 3 teachers is teaching the rest are observer and after class they will talk together about the class on students' learning, objective achieving, and so on. The teachers and students are familiar with outsiders because in each academic year there are a lot of educators and teachers come to visit and learn from these schools.

\section{Methodology}

This study is a case study of qualitative research. The study employed ethnographic study which the researchers participated in this study as a member of

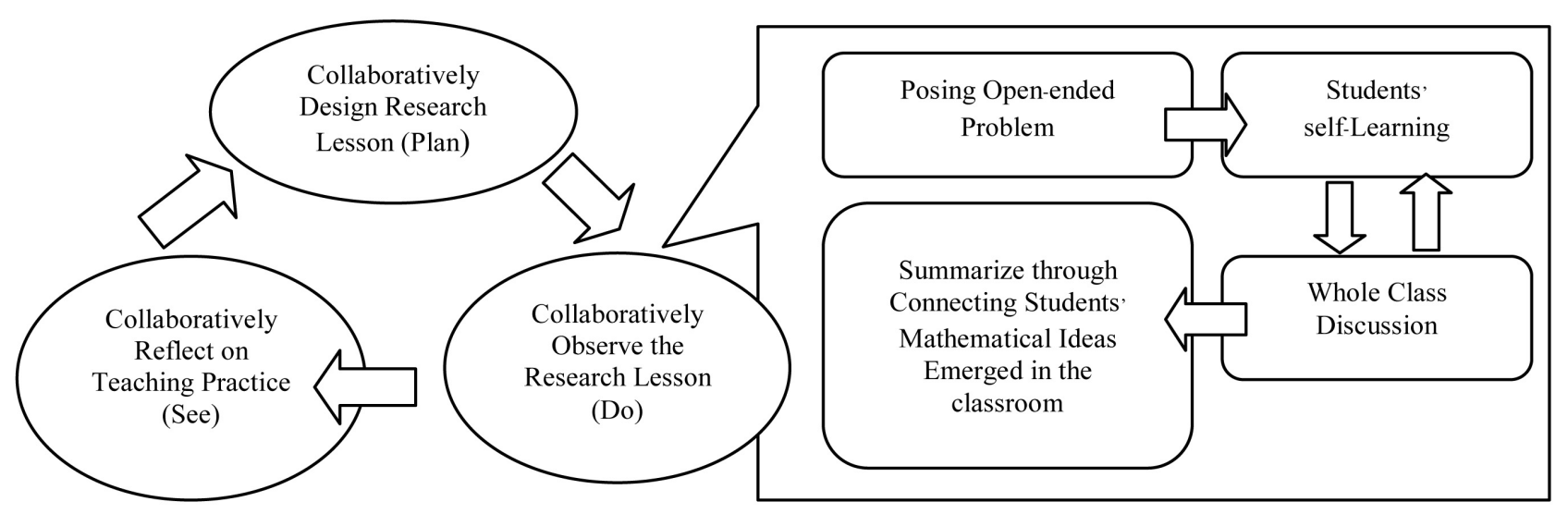

Figure 1. Lesson study incorporating with open approach (Inprasitha, 2011). 
Lesson Study team as an observer and can make a direct observation due to the context of the class as mentioned above and the researchers were familiar with the informants. This brought us to get real situation in this classroom, everything going naturally. First grade mathematics classroom is used as a unit of analysis. The classroom is a case of Lesson Study and Open Approach classroom including 10 first grade students and 3 teachers from Lesson Study team. Data were collected from video-audio tape, teachers and students interview, students' written works, and daily field notes during August-September 2015. There were 9 consecutive lessons on addition recorded by 3 cameras. The outcomes of this study are as interpretation of specific case (Bassey, 1999), that is Lesson Study and Open Approach in Thailand case. During each classroom teaching, one camera focused primary on whole-class teaching. The second camera focused on students' group working. The third camera focused on students' interaction and expression. Moreover, documentation consists of 9 lesson plans on addition; students' written works; daily field notes; and audio taped interview. The data from the video recording of each class was transcribed into protocol to be used for video analysis to analyze students' algebraic reasoning.

\section{Results}

The students in this classroom which has been conducting Lesson Study and Open Approach can show characteristics of algebraic reasoning as following Table 1.

Table 1. Characteristics of algebraic reasoning found in first grade lesson study and open approach classroom.

\begin{tabular}{|c|c|}
\hline Lesson & Characteristics of Algebraic Reasoning \\
\hline $\begin{array}{l}\text { Lesson 1: } \\
\qquad 9+4\end{array}$ & $\begin{array}{l}\text { - Using algebraic expressions to represent addition situation and posing } \\
\text { situation to represent given expressions } \\
\text { - Constructing and using a tool to find problem results more easily } \\
\text { - } \quad \text { Extending solutions to another domain of number }\end{array}$ \\
\hline Lesson 2: $8+3$ & - Extending solutions to another domain of number \\
\hline $\begin{array}{l}\text { Lesson } 3 \text { : How } \\
\text { many eggs? } \\
\qquad(3+9)\end{array}$ & $\begin{array}{l}\text { - Constructing and using a tool to find problem results more easily } \\
\text { - Using algebraic expressions to represent addition situation and posing } \\
\text { situation to represent given expressions }\end{array}$ \\
\hline Lesson $4: 8+6$ & - Using various representation to justify their ways of thinking \\
\hline $\begin{array}{l}\text { Lesson 5: Magic } \\
\text { Flowers }\end{array}$ & - Reasoning about relations among numbers \\
\hline $\begin{array}{l}\text { Lesson 6: Story } \\
\text { telling about } \\
\text { addition }\end{array}$ & $\begin{array}{l}\text { - Using algebraic expressions to represent addition situation and posing } \\
\text { situation to represent given expressions }\end{array}$ \\
\hline $\begin{array}{l}\text { Lesson } 7 \text { : Story } \\
\text { telling about } \\
\qquad 7+8\end{array}$ & $\begin{array}{l}\text { - Constructing and using a tool to find problem results more easily } \\
\text { - Using algebraic expressions to represent addition situation and posing } \\
\text { situation to represent given expressions } \\
\text { - Constructing and using a tool to find problem results more easily }\end{array}$ \\
\hline $\begin{array}{l}\text { Lesson 8: } \\
\text { Addition cards }\end{array}$ & - Reasoning about relations among numbers \\
\hline $\begin{array}{l}\text { Lesson 9: Playing } \\
\text { addition cards }\end{array}$ & - Reasoning about relations among numbers \\
\hline
\end{tabular}


Additionally, we would give an example of each aspect of algebraic reasoning in these following sub-headings.

\subsection{Using Algebraic Expressions to Represent Addition Situation and Posing Situation to Represent Given Expressions}

In one of the lessons that asked the students to represent situation in mathematical sentence after the teacher posted picture on the board as shown as Figure 2.

One of the students said three plus nine and came out to write $3+9$ on the board. Then the teacher asked "how did you know?" She then replied that she saw 3 eggs first and then 9 so she wrote $3+9$. This can be explained that she well understood and linked between a prepared semi-concrete materials and math sentence so she can reason why $3+9$ can represent the picture.

\subsection{Constructing and Using a Tool to Find Problem Results More Easily}

After reviewed the previous lesson, teacher presented new problem situation to the students "How to do with $8+3$ ?" (As shown as Figure 3 ) and before letting them to do group activity there was a student explained his idea as follows:

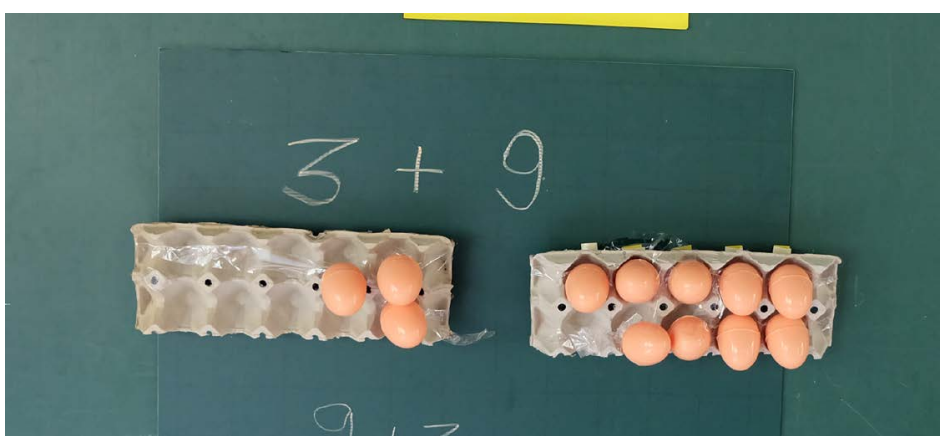

Figure 2. Picture teacher posted on the board.

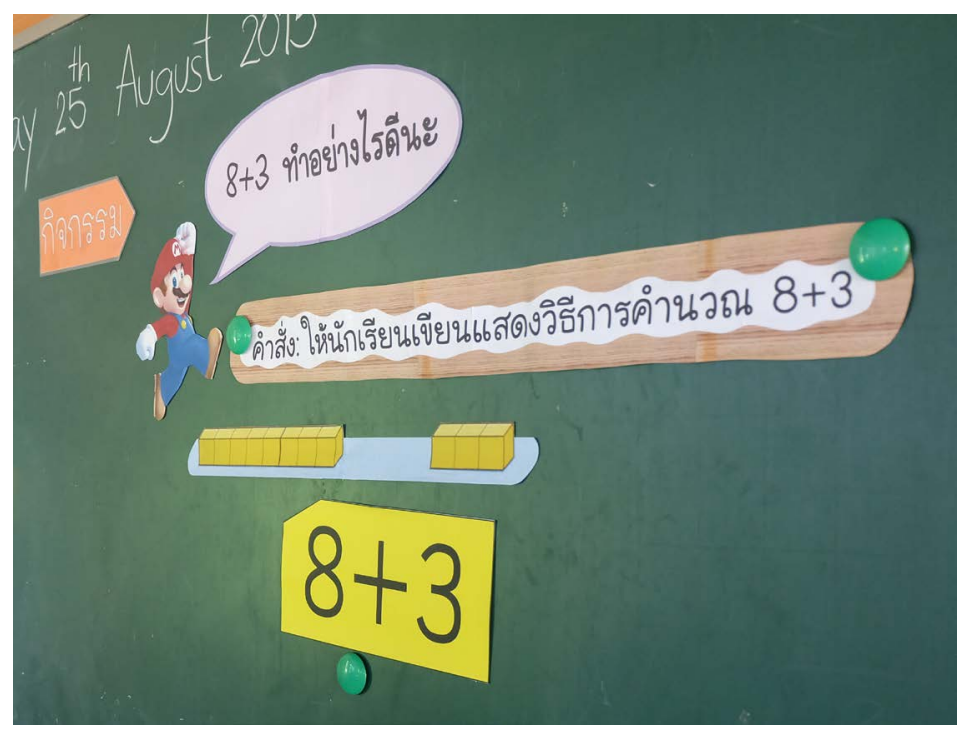

Figure 3. Situation sheet posted on the board "How to do with $8+3$ ?" 


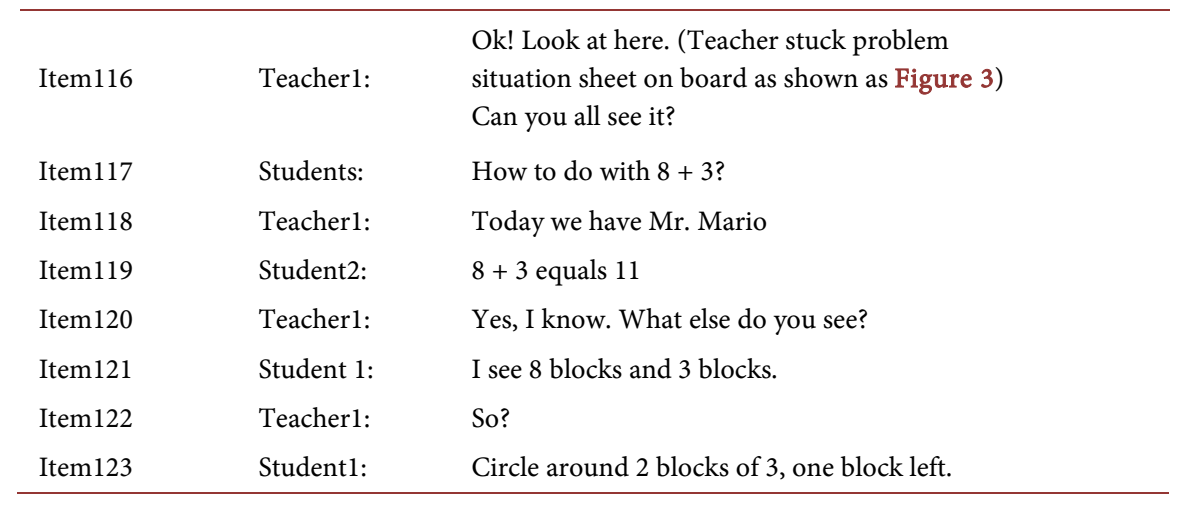

According to student's explanation that "circle around 2 blocks of 3 , one block left" drew us to the question why did he want to use this method. We interviewed him after class and he said that "I want to make 10, if this was 10 (the left-hand side blocks), this could be 11 because there is 1 here" (the right-hand side block) we immediately asked him with question "Why do you need to make 10 ?" and he replied "if it is 10 (he pointed at 8 blocks) I can find the answer because it would be this number" (pointed at 3 blocks). This scenario can explain that student has tried to use an easy way for him to find the answer which is making 10 and he can also reason why he can find the answer by making 10 .

\subsection{Extending Solutions to Another Domain of Number}

Before learning unit Addition (2), the students had learned decomposing number and Addition (1) which is an addition that answer not more than 10. Therefore, they already knew making 10. Throughout these research lessons (Addition 2) they demonstrated using Making 10 method, this means they can extend the method to another domain of number which is addition that answer more than 10. This following scenario is one of examples of extending Making to method to another domain of number.

In this lesson teacher posted the picture which has 9 children playing in sandbox and 4 playing slide and asked the students how many students altogether. Definitely students can immediately reply 13 but the teacher wanted them to do more by asking 2 more questions: 1) Write mathematical sentence 2) Let's think "how to" find number of children. After work in group one group of the students presented their methods and they said "We made a group of 10 and this caused one group of 3, We move 1 child from group of 4 so 3 left and because 4 gave 1 to 9 this would be 10 and 4 was 3 , then 10 and 3 is 13 , so the answer is 13 and we also drew blocks". Students' explanation showed that they used the method that woks for addition which answer not more than 10 to answer more than 10 .

\subsection{Using Various Representation to Justify Their Ways of Thinking}

This scenario will show various kinds of representation that one student used. 
During the $3^{\text {rd }}$ step of Open Approach-whole class discussion, teacher asked students what students did on their worksheet to explain $8+6$.

\begin{tabular}{|c|c|c|}
\hline Item 227 & Student3: & $\begin{array}{l}\text { Then I wrote mathematical sentence } 8+6=14 \text { (using mathe- } \\
\text { matical sentence). The second, I wrote plus } 6 \text { is equal to } 14 \text { and } \\
\text { drew an arrow to show } 6 \text { was decomposed to } 8 \text { so, } 6 \text { left } 4 \text { and } 8 \\
\text { would be } 10 \text { (using diagram). The second way, I made } 8 \text { to leave } \\
4 \text { and } 6 \text { would be } 10 \text { because taking } 4 \text { from } 8 \text { (using diagram). I } \\
\text { also used blocks and I will show you how I used (using blocks) }\end{array}$ \\
\hline Item 228 & Teacher1: & $\begin{array}{l}\text { Can you show us another way? We have } \\
\text { decomposing by } 4 \text { already). Student was using blocks to show } \\
\text { how to add according to her forth way (as shown as Figure } 4 \text { ). }\end{array}$ \\
\hline Item229 & Teacher1: & How many blocks in that side? \\
\hline Item 230 & Student3: & Six. \\
\hline Item 231 & Class: & One, two, three, four, five, six. \\
\hline Item 232 & Student5: & $\begin{array}{l}\text { Six decreased by one, eight decreased by } 3 \\
\text { (Student moved from each of two sides } 5 \text { blocks to } \\
\text { lower position as shown as Figure } 5 \text { ). }\end{array}$ \\
\hline Item 233 & Teacher1: & Let's see. \\
\hline Item34 & Student3: & Then each block is numbered. \\
\hline Item235 & Teacher1: & She makes five and five to be what? \\
\hline Item 236 & Class: & Ten. \\
\hline
\end{tabular}

The student presented us that she can use 1) blocks 2) diagram 3) mathematical sentence to explain her understating on $8+6$. This may claim that the student reason reasonably by using various kinds of representation (blocks, diagram, and mathematical sentence) to justify her own thinking.

\subsection{Reasoning about Relations among Numbers}

In addition card game for the 8th lesson. Teacher asked each group to explain how they arranged the cards and what they've found from arranging the card. One of the scenes can be shown as follows:

The student can show us that he saw relation between each of addends and it' $\mathrm{s}$ increased. He also showed us that he arranged his cards in horizontal lines by considering this relation.

\section{Concluding Remark}

By using Japanese textbook in Lesson Study and Open Approach classroom, the lesson study team can plan the lessons base rather on "how to learn" than finding answer. This conforms to the idea that in order to develop algebraic thinking, not answer should be focused but relations (Kieran, 2004; Cai et al., 2005). Obviously seen in the results section, all lessons focused on how the students get their answers. Thus, students had an opportunity to explain their algebraic reasoning through solving problem (Carraher, Brizuela, \& Schliemann, 2000). 


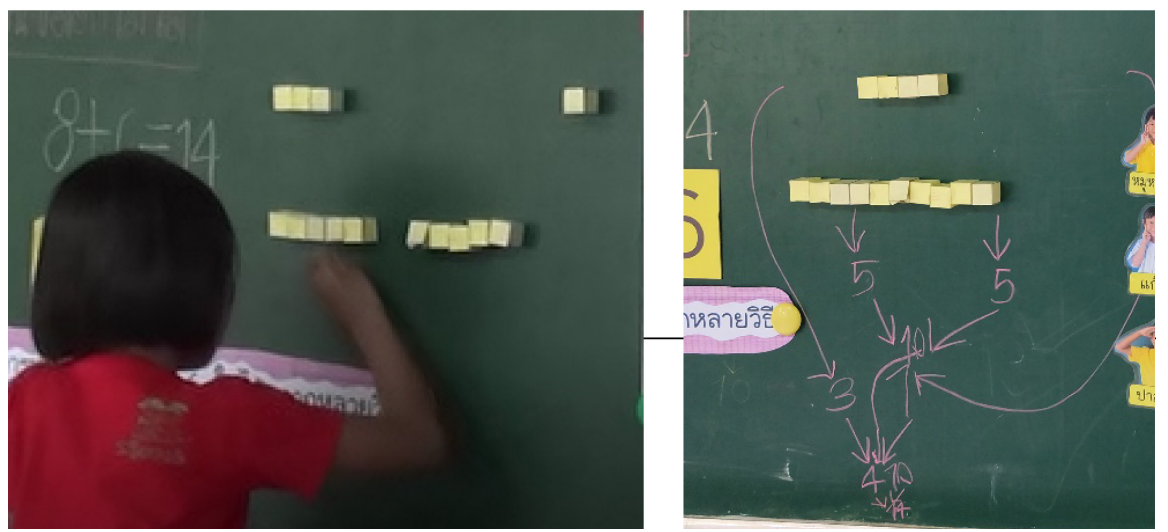

Figure 4. Student using block to explain $8+6$ with her own diagram.

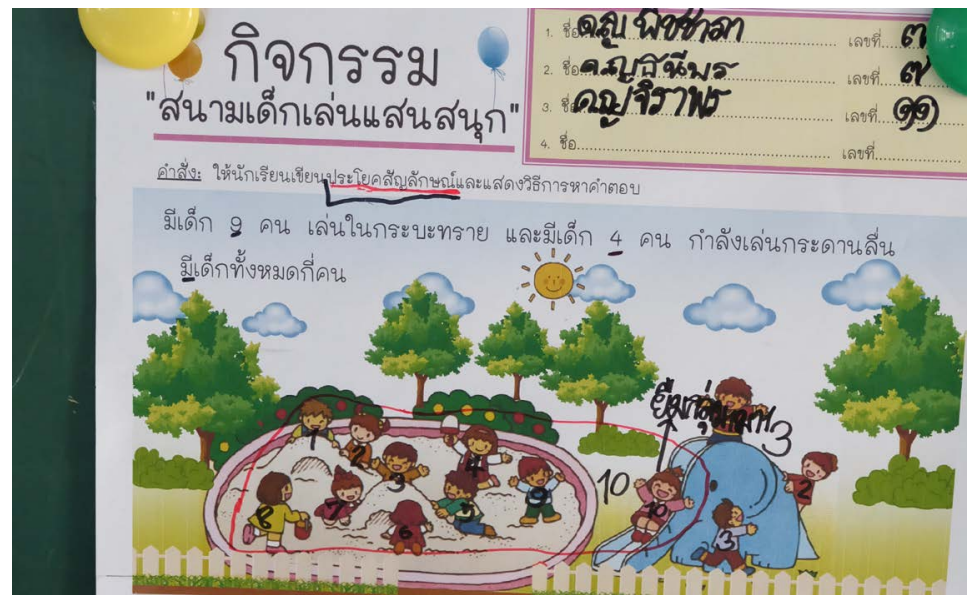

Figure 5. $9+4$ situation.

\begin{tabular}{|c|c|c|}
\hline Item427 & Teacher1: & Ok, explain it. \\
\hline Item 428 & Student1: & $\begin{array}{l}\text { Look at addends, if we look them horizontally, I see they're } \\
\text { increasing (He pointed at the card which is shown as Figure } 6 .\end{array}$ \\
\hline Item 429 & Teacher1: & Everybody gets what he said? \\
\hline Item430 & Students: & Yes. \\
\hline
\end{tabular}

Moreover, the section also shows us that students had their own explanation about numbers and their explanation in 5.1,5.2, 5.3, and 5.4 based on using concrete materials (such as block, picture) and in 5.4 she can make connection between each representation, especially made her own sense on mathematical sentence by linking with concrete materials. Approaching to mathematical world from representation of real world (such as situation, picture) and semi-concrete material can promote such explanation by students. Therefore, using idea of Flow of Lesson which Inprasiha has proposed (2013) can promote students algebraic reasoning. In 5.5 students tried to find rules, which is increased and decreased by 1 . This is the semifinal lesson on addition (2). Even though in this lesson we didn't use concrete materials, students used only number and plus sign which are very mathematics for students, but in previous lessons students 


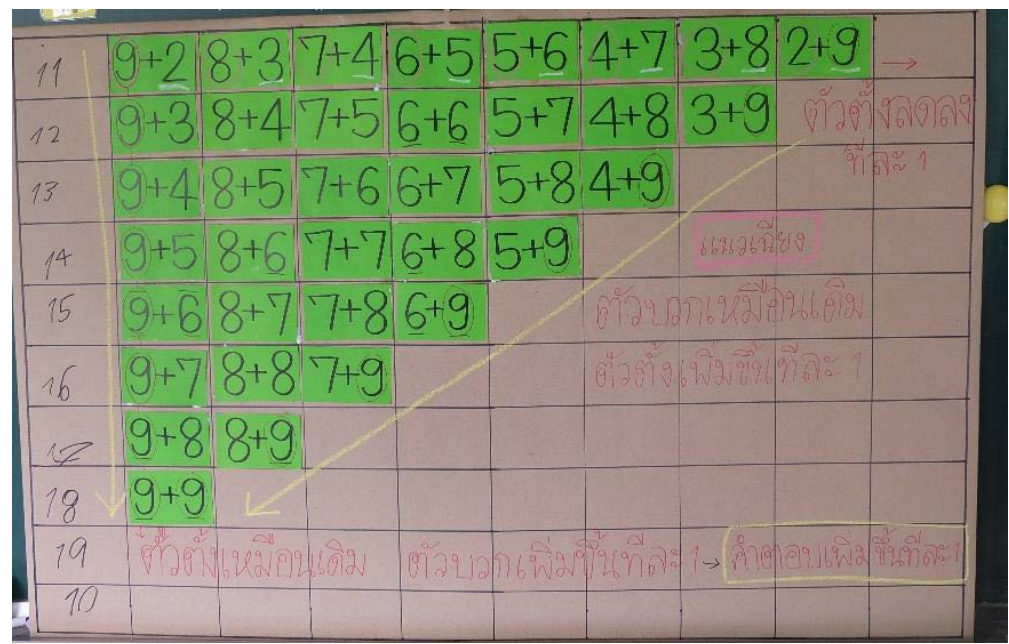

Figure 6. Show arranging addition cards.

learned addition through real world, semi-concrete materials continuously and regularly. This means they can understand math well through learning it from real world and semi-concrete materials so they can see the relations of numbers. Flow of Lesson provides an opportunity to students to see the relations. For all lessons we grounded planning the lesson on Japanese mathematics textbook which does not focus on answer and it is compatible with the idea of flow of lesson. Thus, we can see students' algebraic reasoning in all lessons. Similar to Stephens \& Armanto (2010) found that Japanese textbook series can support students' relational thinking. Thereby, the algebraic reasoning occurred under the condition that teachers and students had connected among 3 worlds oriented to Inprasitha's approach: real world, semi-concrete world, and mathematics world. This means Lesson Study and Open Approach classroom with using Flow of Lesson can promote first grade students' algebraic reasoning.

\section{Acknowledgements}

This work was supported by Thailand Research Fund through the Royal Golden Jubilee Ph.D. Program (Grant No. PHD/0150/2554). We would like to thank you the Project School of Mathematics Teachers Professional Development using Lesson Study and Open Approach for conducting Lesson Study and Open Approach for very long time.

\section{References}

Bassey, M. (1999). Case Study Research in Educational Settings. Buckingham, Philadelphia: Open University Press.

Blanton, M., \& Kaput, J. (2005). Characterizing a Classroom Practice that Promotes Algebraic Reasoning. Journal for Research in Mathematics Education, 36, 412-446.

Blanton, M., \& Kaput, J. (2011). Functional Thinking as a Route into Algebra in the Elementary Grades. In J. Cai, \& E. Knuth (Eds.), Early Algebraization, Advances in Mathematics Education. Berlin Heidelberg: Springer-Verlag.

https://doi.org/10.1007/978-3-642-17735-4_2 
Cai, et al. (2005). The Development of Students' Algebraic Thinking in Earlier Grades: A Cross-Cultural Comparative Perspective. Zentralblattfuer Didaktik der, 37, 5-15.

Carraher, D. W., Schliemann, A. D., Brizuela, B. M., \& Earnest, D. (2006). Arithmetic and Algebra in Early Mathematics Education. Journal for Research in Mathematics Education, 37, 87-115.

Carraher, D., Brizuela, B., \& Schliemann, A.D. (2000). Early Algebra, Early Arithmetic. Treating Operations as Functions. Plenary Address. XXII Meeting of the Psychology of Mathematics Education, North American Chapter, Tucson, AZ: (Available in CD-Rom).

Howden, H. (1990). Prior Experiences. In L. Edwards Edgar, Jr. (Ed.), Algebra for Everyone (Session 1) (pp. 7-23). Reproduced with Permission from Algebra for Everyone by the National Council of Teachers of Mathematics.

Inprasitha, M. (2011). One Feature of Adaptive Lesson Study in Thailand: Designing a Learning Unit. Journal of Science and Mathematics Education in Southeast Asia, 34, 47-66.

Inprasitha, M. (2013). Paper presented at "Workshop for Teachers in the Project School ofMathematics Teachers Professional Development using Lesson Study and Open Approachfor conducting Lesson Study and Open Approach, KhonKaen University".

Inprasitha, M. (2014). Paper Presented at "Workshop on Lesson Study and Open Approach for Demonstration School's Teachers, Khon Kaen University”. Khon Kaen: Khon Kaen University.

Inprasitha, M. (2016a). Personal Communication. Khon Kaen: Khon Kaen University. 19 March 2016

Inprasitha, M. (2016b). Personal Communication. Khon Kaen: Khon Kaen University. 9 August 2016

Isoda, M. (2010). Lesson Study: Problem Solving Approaches in Mathematics Education as a Japanese Experience. Procedia Social and Behavioral Sciences, 8, 17-27. https://doi.org/10.1016/j.sbspro.2010.12.003

Jacobs, et al. (2007). Professional Development Focused on Children's Algebraic Reasoning in Elementary School. Journal for Research in Mathematics Education, 38, 258-288.

Kieran, C. (2004). Algebraic Thinking in the Early Grades: What Is It? The Mathematics Educator, 8, 139-151.

Lins, R., \& Kaput, J. (2004). The Early Development of Algebraic Reasoning: The Current State of the Field. In K. Stacey, H. Chick, \& M. Kendal (Eds.), The Future of the Teaching and Learning of Algebra: The 12th ICMI Study, Dordrecht: Kluwer Academic Publishers. https://doi.org/10.1007/1-4020-8131-6_4

Lodholz, R. (1990). The Transition from Arithmetic to Algebra. In E. L. Edwards (Ed.), Algebra for Everyone (Session 1, pp. 24-33). Reston, VA: The National Council of Teachers of Mathematics.

NCTM (1990). Algebra for Everyone. Reston, VA: The National Council of Teachers of Mathematics.

NCTM (2000). Principles and Standards for School Mathematics. Reston, VA: National Council of Teachers of Mathematics.

Radford, L. (2012). Early Algebraic Thinking: Epistemological, Semiotic, and Developmental Issues. In: S. Cho (Eds.), The Proceedings of the 12 th International Congress on Mathematical Education. Cham: Springer.

Shimada, S. (1997). The Significance of an Open-Ended Approach. In J. Becker, \& S. Shimada (Eds.), The Open-Ended Approach: A New Proposal for Teaching Mathe- 
matics. Reston, VA: Author.

Smith, J., \& Thompson, P. W. (2007). Quantitative Reasoning and the Development of Algebraic Reasoning. In J. J. Kaput, D. W. Carraher, \& M. L. Blanton (Eds.), Algebra in the Early Grades (pp. 95-132). New York, NY: Erlbaum.

Stacey, K., \& Chick, H. (2004). Solving the Problem with Algebra. In K. Stacey, H. Chick, \& M. Kendal (Eds.), The Future of the Teaching and Learning of Algebra: The 12th ICMI Study (1-20). Dordrecht: Kluwer Academic Publishers. https://doi.org/10.1007/1-4020-8131-6_1

Stephens, M., \& Armanto, D. (2010). How to Build Powerful Learning Trajectories for Relational Thinking in the Primary School Years. In L. Sparrow, B. Kissane, \& C. Hurst (Eds.), Shaping the Future of Mathematics Education: Proceedings of the $33^{\text {rd }}$ Annual Conference of the Mathematics Education Research Group of Australasia (523-530). Fremantle: MERGA.

Stigler, J., \& Hiebert, J. (1999). The Teaching Gap: Best Ideas from the World's Teachers for Improving Education in the Classroom. New York: Free Press.

Yackel, E. (1997). A Foundation for Algebraic Reasoning in the Early Grades. Teaching Children Mathematics, 3, 276-280. 